\title{
Research on the current situation and Countermeasures of tennis teaching and training in Colleges and Universities
}

\author{
Lihua Wang, a , Lichun Yang, ${ }^{2, b}$ Jin Suo $^{1, c}$ \\ ${ }^{1}$ Colege of physical education, Yunnan agricultural university, Kunming 650201, China \\ ${ }^{2}$ Ministry of sports, sun yat-sen university, Guangzhou 510275, China \\ alihuaww98@163.con, byangchun19@126.com, csuojin367@163.com
}

Keywords: tennis; teaching; training

\begin{abstract}
With the popularity and popularity of tennis in China, tennis has become a part of comprehensive sports teaching in China. College tennis club, largely to promote the college tennis teaching activities, but the college tennis teaching activities in the development is still restricted by many negative factors, the status qua of college tennis teaching is not good, the lack of scientific and feasibility of teaching and training of college tennis teaching quality also leads to relatively low. This article will analyze the current situation of tennis teaching and training in colleges and universities. On the basis of the problems existing in the development of tennis teaching and training in colleges and universities, this paper puts forward some reasonable suggestions on how to better carry out tennis teaching and training in colleges and universities.
\end{abstract}

\section{Introduction}

Tennis teaching and training in colleges and universities is very important for students to master tennis skills, and to develop tennis teaching and training in an irrational way will exert more influence on the students' mastery of tennis skills. At this stage, there are many problems in tennis teaching and training in colleges and universities. Countless schools haven't made a good distinction between tennis teaching and tennis teaching and training, which has also led to poor tennis teaching and training. Under the new era, college tennis teachers are paying more and more attention in college tennis teaching and training related activities, but the effect of tennis teaching and training in tennis teaching many students just passable, training effect is not reasonable, it is for the sport of tennis has gradually lost interest[1].

\section{Tennis teaching in colleges and universities}

The domestic university, tennis teaching is an important component in the teaching of physical education, tennis popularization, many college students have a keen interest in tennis, college tennis teaching in this context has been the relatively rapid development. Tennis teaching and training are a very important form of teaching in college tennis. Generally speaking, students with better training can perform well in tennis. From the game of tennis itself, tennis is a kind of technology, physical strength and coordination requirements of high complexity of ball games, tennis itself also makes the college tennis teaching in carrying out the difficult. Tennis itself has these characteristics make tennis teaching and training activities in colleges and universities cannot easily carry out, affected by internal and external factors, tennis teaching and training related activities can not be better. Tennis teaching in colleges and universities is not only an important part of physical education in Colleges and universities. In the new curriculum reform, tennis teaching in colleges and universities is even more enriched for teaching content and a better choice. But also need to see, exist in college tennis 
teaching and training activities in a series of problems is very obvious, related problems cannot be solved in time, more affected the effectiveness of tennis teaching in colleges and universities. How to better develop tennis teaching and training activities in colleges and universities has become a practical problem for college teachers to think about.

\section{Tennis teaching and training in Colleges and Universities}

\section{Tennis teaching and training system is poor}

The specific problems of poor tennis teaching and training system of college tennis teaching and training, training in tennis teaching system under the influence of poor control ability, teacher training activities for the tennis teaching is obviously insufficient, students in the lack of systematic training in tennis teaching activities under the influence, not only to better participate in tennis teaching no more training, tennis related skills and knowledge to better grasp. The system training principle is the universal principle which needs to be followed in the training of the kinematics. It is likewise the basic requirement of human biology and kinematics to carry on the training step by step and step by step. However, tennis teaching in colleges and universities to carry out training activities, few teachers will systematically develop training programs, extensive tennis teaching and training activities is also a lot of College Tennis Teaching in the training activities carried out on the common practice. Under the influence of the lack of tennis teaching and training system in colleges and universities, some tennis teaching and training content will occur frequently, and there are many tennis training content cannot be mentioned. Under limited class hours, tennis teaching and training in colleges and universities cannot systematically take into account the various training content, but also lead to tennis teaching and training effect can not be consistent with the expected objectives. What is more serious is that once tennis teaching and training is not systematic, relevant tennis teaching and training measures cannot give full play to the value and role of training in the implementation and implementation[2].

\section{The importance of tennis teaching and training is low}

The importance of the tennis teaching and training activities in colleges and universities is low. In the tennis teaching and training activities lack of due attention. The related training activities cannot be better supported and coordinated. Tennis teaching and training, communication between teachers and students can affect the final results of training, but the part of university tennis teaching present situation analysis can be found, a lot of teachers to carry out training activities in tennis teaching, and students do not actively in communication and contact, it also makes a lot of students gradually produce the wrong cognition of tennis teaching, many students do not even want to actively participate in the tennis teaching and training. Although in recent years the tennis movement in domestic colleges and universities are well spread, the number of tennis fans in college students is large, but compared to basketball, football and other traditional tennis ball games, the audience is relatively small, many college students for the tennis movement is still relatively unfamiliar, part of the actual status of college tennis teaching is weak, many teachers in the teaching of tennis training activities carried out on the randomness is also more obvious. When the school support is weak and the teachers and students do not pay enough attention to it, the related activities of tennis teaching and training in colleges and universities cannot be carried out naturally[3].

\section{Teachers are weak in tennis teaching and training}

Most of the physical education teachers in Colleges and universities tennis the rise in recent years, the movement can not be teaching planning, many teachers in tennis teaching and training do not understand the situation in tennis teaching and training activities, also affects the teaching effect of tennis training activities. The teacher as the leading tennis teaching and training, affect their training in tennis teaching is very direct and obvious, weak professional ability of college tennis teaching training of teachers, the corporation not to tennis teaching activities associated with the effective promotion of practical help. As mentioned earlier, tennis has a higher degree of complexity, and tennis teaching and training are a better opportunity to constantly hone and improve tennis skills and skills". Teachers in tennis teaching and training on professional ability is insufficient, will directly 
lead to many key tennis training contents cannot exist in the training system, some teachers in tennis teaching and training of professional ability has been lacking, nor the tennis teaching and training for better control and planning, innovative training to enhance the tennis teaching is basically impossible. In more emphasis on tennis teaching and training professional background, teachers in professional ability of the shortage are very abrupt and obvious.

\section{Tennis teaching and training are out of practice}

The teaching of tennis training, tennis teaching and training activities from each other and the actual needs of students of the phenomenon is very obvious and generally ignored, tennis itself features and students' tennis ability based tennis teaching and training, achieve not only conducive to the tennis teaching goal, but for tennis teaching and training activities are hidden negative impact carry out. It is worth noting that, although a lot of college students for the tennis movement is of interest, but the vast majority of college students in junior high school and senior high school stage did not come into contact with the tennis, the tennis ability was weak. Some college tennis teachers ignored in teaching and training the present situation of the choice of training content. Some students cannot achieve the goal in teaching and training, enthusiasm for tennis and tennis teaching and training can't be promoted. Many teachers' unreasonable tennis teaching and training content cannot help students lay a solid foundation for tennis. It is also because of tennis teaching and training and practice disjointed, the overall level of college tennis teaching and training has been low, although some teachers have made great efforts for the tennis teaching and training, but the imbalance of tennis teaching and training input and actual output effect between the ten is still obvious[4].

\section{Better recommendations for Tennis teaching and training in Colleges and universities}

\section{Making tennis teaching and training programs scientifically}

Tennis teaching and training in Colleges and universities better, requiring teachers to carry out scientific tennis training program formulation, and through systematic training program to carry out specific tennis teaching and training activities. Tennis teaching and training itself is complex. Tennis teaching and training related programs should pay attention to professionalism, science and feasibility of both. Suggestions of college tennis teachers in tennis training teaching plan formulation, fully respect the tennis training practice, based on a better reference tennis related scientific training system, establish conforms to the actual teaching and training plan. Tennis teachers in Colleges and universities in tennis teaching and training plan after the completion of the teaching and training program should be flexible use of tennis. The college tennis teaching and training activities will be carried out in the internal and external factors, therefore, the tennis training plan of teaching should not be rigid compliance, teachers need to keep on tennis teaching and training plan to adjust and play tennis teaching and training plan scientific guidance, the tennis teaching and training activities to help students to learn about tennis, and enable students to master more skills and scientific skills of tennis[5].

\section{Increase the importance of tennis teaching and training}

College tennis teaching better also needs to increase attention training in tennis teaching, and create a tennis teaching and training activities of the internal environment, so as to reduce the adverse effects of internal and external factors to carry out training activities in tennis teaching. Specifically, in the context of the new curriculum reform, colleges and universities are required to optimize the school physical education system, on the basis of ensuring adequate tennis teaching hours, and constantly enhance the importance of tennis teaching. In view of higher school tennis teaching status is not good, and the tennis teaching resources is relatively small, universities can use the tennis club with the advantages of resources, to further promote the popularization of tennis in the school, so that students can have a more in-depth understanding of tennis. Tennis teaching and training for various teaching facilities are more dependent on university tennis teaching better, also need to increase the tennis teaching related infrastructure construction and speed, through the construction of professional tennis teaching and training venues to make tennis teaching in various functional areas can be parallel exists, effective selection is also a good tennis teaching and training. In the more stressed the 
effectiveness of tennis teaching and training under the background of universities is to focus on tennis teaching and training activities to create the internal environment, which makes the training activities related to teaching can get more support in the development, the background, existing in the University Tennis Teaching and training in all kinds of problems can be solved.

\section{Enhance the professional quality of related teachers}

The college tennis teaching and training are better to improve teachers' professional qualifications from the start, especially the influence of many professional tennis teachers in Colleges and universities is low at this stage is very obvious, to enhance the professional quality of teachers can obviously promote college tennis teaching and training activities carried out smoothly. It is suggested that the team of teachers of physical education should be better reconstructed within the University, and that the physical education teachers who are familiar with the relevant knowledge of tennis and tennis teaching and training should be responsible for the specific tennis teaching and training activities. In addition, colleges and universities should regularly carry out professional skills training for tennis teaching and training teachers, so that their own professional quality can be better promoted. High school tennis teachers should also through the Internet and other channels for tennis teaching and training related knowledge acquisition, so that their tennis teaching and training activities can continue to enhance. College Tennis teachers' skilled accomplishment includes multiple dimensions, in college tennis teachers limited time and energy, it should better find themselves in tennis teaching and training activities on the ability of existing problems, and targeted for special ability. Only when the professional quality of tennis teachers in Colleges and universities has been improved, tennis teachers in Colleges and universities can better control tennis teaching and training, so as to ensure that tennis teaching and training activities can be performed normally[6].

\section{Carrying out tennis teaching and training activities in combination with practice}

The better development of tennis teaching and training in colleges and universities should pay attention to the combination of tennis teaching, training activities and practice, so as to avoid the phenomenon of disconnection between tennis teaching and training activities and practice. Specifically, teachers are responsible for teaching and training activities should be in advance of the tennis tennis teaching and training activities for better planning, and fully understand the tennis teaching and training practice, students' ability of tennis practice, students' learning ability practical basis, how to carry out the training of tennis teaching thinking and planning activities. College Tennis teachers in tennis teaching and training, through the observation of students training to various training modes, comparison and analysis of training methods of practical value, can also be based on students' training performance found that students in the teaching of tennis training problem. A good grasp of the actual teaching and learning practice basis, students for the strange feeling of tennis teaching will be gradually reduced, in tennis teaching and training students' practical activities and better fit, the continuous development of tennis teaching can make students have a better performance in tennis, it clearly helps to enhance students' interest in tennis sports and sports enthusiasm. It is worth noting that, in the students' tennis ability level is uneven, the teachers can use group teaching to carry out specific training activities so as to make the teaching of tennis, tennis teaching training is more targeted[7].

\section{Conclusion}

In University Tennis Teaching and training, the teacher's leading role and guiding role are understandable. Tennis teachers in colleges and universities also need to shoulder the responsibility of planning tennis training and teaching and promoting the effectiveness of tennis training teaching. In colleges and universities, many tennis enthusiasts have poor Tennis Foundation, and their performance in training ground and sports field is obviously different. Therefore, tennis teachers in colleges and universities need to give full consideration to the teaching practice in tennis training class, so that tennis training teaching can be more targeted. The concept of sunshine sports education has been deeply rooted in the hearts of the people. The development of tennis teaching and training 
activities in colleges and universities should also pay attention to the transformation of ideas, and rely on more advanced ideas to carry out related activities of tennis teaching and training.

\section{References}

[1] Yuhuan. Study on Current Situation and Countermeasures of English Language Culture Teaching for English Majors in Local Normal Universities[J]. International Journal of Technology Management, 2013:14-15.

[2]Iserbyt P, Madou B, Elen J, et al. Task Card Instruction: The Effect of Different Cue Sequences on Students' Learning in Tennis.[J]. European Physical Education Review, 2010, 16(3):237-249.

[3]Alkhalaf M M T, Diabat M K. The Effect of Using Command and Reciprocal Teaching Styles, In Learning Basic Skills For Beginners in Table Tennis[J]. Learning Disability Quarterly, 2013, 37(2):87-99.

[4]Yuan S. Current Situation and Countermeasures for the Enrollment of Adult Higher Education in Agricultural Colleges:Example of Yunnan Agricultural University[J]. Journal of Biochemistry, 2013, 153(1):43.

[5]Beckett K D. The Effects of Two Teaching Styles on College Students' Achievement of Selected Physical Education Outcomes.[J]. Journal of Teaching in Physical Education, 2010, 10(2).

[6]Alkhalaf M M T, Diabat M K. The Effect of Using Command and Reciprocal Teaching Styles, In Learning Basic Skills For Beginners in Table Tennis[J]. Learning Disability Quarterly, 2013, 37(2):87-99.

[7]Zhang P, Ward P, Li W D, et al. Effects of play practice on teaching table tennis skills.[J]. Journal of Teaching in Physical Education, 2012, 31(1):71-85. 